DOI: 10.33766/2524-0323.89.110-120

УДК 343.98

\author{
К. А. Шаповал, \\ ад'юнкт відділу організації \\ освітньо-наукової підготовки \\ Харківського національного \\ університету внутрішніх справ \\ (м. Харків, Україна) \\ e-mail: katjshapoval@ukr.net \\ (iDhttps:// orcid.org/0000-0003-1826-5261
}

\title{
КРИМІНАЛІСТИЧНА КЛАСИФІКАЦІЯ ВБИВСТВ IЗ ЗАСТОСУВАННЯМ ДОМАШНЬОГО НАСИЛЬСТВА
}

У статті розкрито криміналістичну класифікацію вбивств, вчинених у зв'язку із застосуванням домашнього насильсва. На основі вивченої наукової літератури, судової та слідчої практики розглянуто критерії для формування криміналістичної класифікації вбивств, вчинених у зв' язку із застосуванням домашнього насильства. Визначено поняття вбивства, його класифікації та домашнього насильства.

Ключові слова: криміналістична класифікація, вбивство, домашнєе насильство, злочин, життя.

Постановка проблеми. Останнім часом у суспільстві значного поширення набуває проблема домашнього насильства. У зв' язку з цим значні зусилля багатьох державних органів та громадських організацій зосереджуються на проблеми протидії домашньому насильству. Однак домашнє насильство - це не тільки проблема, яка має сощіальний характер, вона набуває масштабів суспільно небезпечних явищ, за які нині законом передбачено кримінальну відповідальність. Так серед злочинів проти життя й здоров'я особи найбільш небезпечними є вбивства.

Судова та слідча практика свідчить про те, що багатьом вбивствам, вчиненим відносно одного $з$ подружжя, передує неодноразові факти вчинення домашнього насильства.

Домашньому насильству в Україні сьогодні приділяється значна увага. Зокрема Кримінальний кодекс України (далі - КК України) доповнено ст. 126-1 «Домашнє насильство» [1], також прийнято Закон України «Про запобігання та протидію домашньому насильству» [2]. Ці зміни спонукають до розроблення окремої криміналістичної класифікації вбивств, що вчиняються із застосуванням домашнього насильства та висунення рекомендащій щодо можливих моделей їі застосування в практичній діяльності.

Різноманітність обстановки злочинів, способів їх вчинення, мотивів та мети, специфічність використовуваних злочинцями знарядь і засобів обумовлюють необхідність особливого тактичного підходу щодо розслідування зазначеної категорії кримінальних правопорушень. Класифікація й оптимізація даного виду злочинів значно полегшить роботу правоохоронних органів у розкритті та розслідуванні тяжких та особливо тяжких злочинів, оскільки наразі класифікащія вбивств, учинених через домашнє насильство відсутня, тому дана проблема набуває актуальності.

(C) Шаповал К. А., 2020 
Аналіз останніх досліджень і публікацій. Проблема класифікації злочинів розглядалася багатьма кримінологами. Дослідженню цього питання присвячували свої роботи: Ю. Антонян, О. Головін, А. Зелінський, О. Джужа, Л. Кондратюк, Л. Кривоченко, В. Кудрявцев та ін.

Проблеми насильства детально розглядали та викладали його основні теорії у своїх дослідженнях О. Дудоров, М. Хавронюк [3], Ю. Шемшученко [4]. Проблеми профілактики та протидії насиллю в сім'ї досліджували такі вчені, як: О. Бандурка, А. Блага, О. Джужа, Л. Крижна, О. Костирь, Ю. Крупка, К. Левченко, О. Литвинов, Г. Мошак, М. Панов, Я. Сотак, О. Старков та ін.

Методика умисних вбивств також досліджувалося багатьма вченими, тому ці проблеми висвітлені в наукових працях. Вагомий внесок у розробку даної проблеми внесли такі вчені-криміналісти, як: О. Андрєєв, Р. Бічурін, І. Борисенко, В. Бояров, О. Булулуков, О. Галаган, М. Данышин, В. Дрозд, В. Журавель, С. Здоровко, В. Гузєй, В. Гусєва, А. Іваниця, І. Когутич, В. Колмаков, Ю. Комаринська, В. Коновалова, М.Костенко, І. Кубарєв, Т. Лускатова, В. Малярова, В. Назаров, О. Одерій, І. Петрова, В. Польщиков, В. Пчолкін, О. Саінчин, С. Сафронов, В. Семеногов, В. Синчук, Р. Степанюк, А. Чорний, В. Шендрика, А. Шеремет, А. Шульга, О. Юхно та інші.

Однак серед учених існує чимало суперечностей щодо критеріїв класифікації окремих видів злочинів, зокрема вбивств, які вчиняються із застосуванням домашнього насильства.

Формулювання цілей. Метою даної статті є детальний аналіз різноманітних типових підходів до класифікації вбивств, які вчиняються із застосуванням домашнього насильства (побутових вбивств) та встановлення їі оптимальних критеріїв. Отже, новизна міститься у визначенні критеріїв побудови комплексної криміналістичної класифікащії даного виду злочинів. Розроблення класифікації вбивств обумовлене практичними потребами вдосконалення розслідування даної категорії злочинів, розроблення методики їх розслідування та є вагомим елементом під час формування кримінологічного аналізу, особливостей детермінації різних видів злочинів та, відповідно до цього, розроблення превентивних заходів у протидії домашньому насильству та усуненню його негативних наслідків.

Окрема підвидова методика розслідування вбивств, вчинених із застосуванням домашнього насильства, залишається поза увагою та потребує подальшого розширення та деталізаціі. Для сприяння оперативного розслідування та розгляду даного виду злочинів є необхідність розроблення криміналістичної класифікації вбивств, вчинених із застосуванням домашнього насильства, а також визначення можливих сфер застосування розроблених рекомендацій по використанню даної класифікації.

Виклад основного матеріалу. Особлива тяжкість цього злочину обгрунтовується багатьма науковцями в галузі кримінального права, про що свідчить санкція статті, яка передбачає позбавлення волі до п'ятнадцяти років. Зокрема М. Коржанський зазначає, що вбивство - це один із найбілыш тяжких злочинів. Убивство позбавляє потерпілого найщіннішого блага - життя. Наслідки цього злочину безповоротні. Крім того, убивство завдає надзвичайно тяжкої наслідки не тільки потерпілому, але і його рідним, і близьким. Убивство - це трагедія для всіх, хто його бачить, хто про нього знає [5, с. 41]. Саме тому, у Конституції України, а також у багатьох міжнародних документах (конвенціях, договорах) закріплене невід' ємне право кожного на життя, яке визнається найбільшою соціальною цінністю в суспільстві та державі. 
Відповідно до ст. ст. 3 і 27 Конституції України, людина, ії життя і здоров'я, честь і гідність, недоторканність і безпека визнаються найвищою соціальною цінністю. Кожний має невід'ємне (абсолютне) право на життя. Права і свободи людини та їх гарантії визначають зміст і спрямованість діяльності держави, яка відповідає перед людиною за свою діяльність. Утвердження і забезпечення прав і свобод людини є головним обов' язком держави. Ніхто не може бути свавільно позбавлений життя. Обов' язок держави - захищати життя людини. Кожен має право захищати своє життя і здоров' я, життя і здоров' я інших людей від протиправних посягань [6]. Убивства, які скоються у зв' язку із домашнім насильством, забирають найщінніше, що має людина, - це ії життя.

За даними статистики Генеральної прокуратури України, що відбито в «Сдиному звіті про кримінальні правопорушення», можна спостерігати наступні статистичні дані за 2018-2019 роки [7]. Усього зареєстровано 487133 кримінальні правопорушення (за 2018 рік) і 444130 - за 2019 рік; із них пов' язаних із насильством у сім'ї1586 випадки в 2018 році проти 2554 - у 2019 році. Особами, які раніше вчиняли кримінальні правопорушення протягом 2018 року, скоєно 317 правопорушень, а в 2019 році - 688. Особи, які скоювали кримінальні правопорушення, пов'язані 3 насильством у сім'ї, і перебували в стані алкогольного сп'яніння, вчинили 550 кримінальних правопорушень за 2018 рік і 857 - за 2019 рік відповідно.

Тож на основі статистичних даних можемо зробити висновки, що кількість кримінальних правопорушень, учинених із застосуванням домашнього насильства, зростає. Також прослідковується збільшення випадків скоєння домашнього насильства особами, які перебували в стані алкогольного сп' яніння. Однак статистичні дані про вчинення вбивств у зв'язку з домашнім насильством відсутні, але даний вид злочинів набуває більш широких масштабів та потребує детального аналізу. Необхідним є висунення пропозицій виокремлення його в окремий вид убивств із кваліфікуючою ознакою «із застосуванням домашнього насильства».

Етимологічно термін «убивство» походить із латинського «һото» («людина») та «caedo» («вбивство»), також може використовуватися термін «гоміцид». Юридичне визначення поняття «умисне вбивство» міститься в частині 1 статті 115 КК України. Зокрема, відповідно до вказаної статті, під умисним убивством розуміється «умисне протиправне заподіяння смерті іншій людині» [1]. 3 огляду на зазначену конструкцію норми, можна виокремити основні ознаки умисного вбивства:

- винність (тобто наявність вини, яка полягає в ставленні особи до вчинюваної дії чи бездіяльності та їі наслідків, виражене у формі умислу);

- протиправність (означає, що таке діяння заборонене кримінальним законом під загрозою кримінального покарання

- заподіяння смерті (тобто припинення життя людини внаслідок вчинених дій).

Щодо наукового підходу до визначення поняття «вбивство», варто наголосити на позищії позищію вітчизняного вченого-спеціаліста в галузі кримінального права Ю. Бауліна, який зазначає, що «вбивство необхідно розуміти, як протиправне умисне позбавлення життя іншої особи, вчинене суб' єктом злочину за відсутності обставин, що виключають протиправність такого діяння» [8, с. 19]. Також окремі науковці пропонують під вбивством розуміти «суспільно небезпечне протиправне діяння, 
вчинене особою, що підлягає кримінальній відповідальності, і полягає в умисному позбавленні життя іншої людини» [9, с. 112].

Важливою складовою методики розслідування вбивств із застосуванням домашнього насильства є формування криміналістичної класифікації даного виду злочинів.

Класифікація злочинів - це необхідна умова ефективного пізнання даного об'єкта, важливий засіб проникнення у його глибинні базисні шари та забезпечення продуктивного руху думок дослідників від вихідного цілого до частин, що його складають, i від них знову до цілого для виявлення закономірностей, знання яких необхідно для його наукового пояснення та описання [10, с. 4].

Під класифікацією розуміється розподіл предметів, явищ на класи, які проведено таким чином, що кожний клас займає відносно інших класів точно встановлене місце [11, с. 59]. Поділ їх на групи залежно від того чи іншого критерію [12, c. 75], тобто розподіл злочинів за групами на підставі тих або інших суттевих ознак, або поділ злочинів на однорідні групи. Класифікація здійснюється, виходячи з умов формальної логіки. Цю дію необхідно проводити з урахуванням таких методів теорії пізнання, як системний підхід до вивчення окремих об'єктів і явищ, висування гіпотез, моделювання [13, с. 97].

На думку О. Головіна, класифікація є складовою криміналістичної систематики. Тобто розуміння класифікації, як поділу поняття, результатом якої є створення системи супідрядних понять або розподілу предметів, явищ, стосунків, властивостей на класи, групи, види, по суті є опис однієї і тієї ж логічної процедури [14, с. 38]. Виходячи з цього, можна зробити висновок, що класифікація - це процес систематизації інформації шляхом розподілу їі на блоки за спільними ознаками.

Головною метою будь-якої класифікації виступають типові об'єктивні ознаки, на підставі яких можна групувати об'єкти класифікації, визначати їх місце в категоріальному просторі. Водночас сенс класифікації полягає в поглибленні знань про самі об'єкти, бо повніше й глибше дійсна сутність явищ та їх властивостей може проявитися лише у зв' язку, у порівнянні з іншими, що дає можливість глибше досліджувати явище в цілому, побачити його розвиток і вплив на інші явища [15, с. 14-15].

Традищійно в криміналістищі класифікація злочинів будувалася, виходячи 3 системи кримінального закону, залежно від того, до якої глави КК належать ті чи інші норми. Недарма в спеціальній літературі неодноразово відзначалося значення кримінального права у формуванні комплексів окремих криміналістичних методичних рекомендацій. Кримінально-правова класифікація злочинів служить основою для розроблення криміналістичних класифікацій злочинів, які використовуються для систематизації окремих криміналістичних методик розслідування за способом та місцем вчинення злочину, особи злочинця, предмету злочинного посягання та іншим підставам криміналістичного характеру [16, с. 20].

Саме поняття криміналістичної класифікації злочинів є достатньо новим та дискусійним у криміналістиці. Під криміналістичною класифікацією розуміється їх систематизація за криміналістично значущими підставами, що сприяе формуванню криміналістичних характеристик злочинів і розроблення окремих криміналістичних методик $[17$, с. 9]. У криміналістиці тривалий час використовувалася кри- 
мінально-правова класифікація злочинів для виконання різних завдань, яку ми використаємо за основу під час формування криміналістичної класифікації вбивств із застосуванням домашнього насильства.

Залежно від мети і завдань. застосовуються різні підходи щодо групування чи класифікації злочинів, що знаходяться в основі структурування злочинності. Питання про критерії (підстави) класифікації - найважливіше в проблемі побудови класифікації злочинів, оскільки критерії є показником теоретичного і практичного значення класифікації в цілому, тих цілей і задач, що перед нею ставляться [18, с. 27].

Криміналістична класифікація вбивств, вчинених у зв'язку $з$ домашнім насильством, у значній кількості базується на нормах, які прописані в Кримінальному кодексі України, але існують також не кримінально - правові критерії, які допомагають скласти кримінологічну класифікацію вбивств із застосуванням домашнього насильства. До них ми можемо віднести місце вчинення злочину, наявність свідків тощо.

Убивства, вчинені у зв'язку з домашнім насильством, на нашу думку, можна розподілити на дві основні групи та класифікувати їх за кримінально -правовими ознаками відповідно до положень Особливої частини КК України та за суб'єктом скоєння вбивства:

Перша - це ті, які вчинені особою, що вчинила домашнє насильство в будь-якій формі [2]. До них належать убивства, передбачені ч. 2 ст. 115 КК України [1], а саме: двох або білыше осіб (п. 1); малолітньої дитини або жінки, яка завідомо для винного перебувала в стані вагітності (п. 2); вчинене з особливою жорстокістю (п. 4); вчинене способом, небезпечним для життя багатьох осіб (п. 5); поєднане із згвалтуванням або насильницьким задоволенням статевої пристрасті неприродним способом (п. 10).

Другу групу складатимуть убивства, що направлені на особу кривдника, тобто вбивства, які скоює потерпіла від домашнього насильства особа. До другої групи можна віднести злочини:

- убивство, вчинене у зв' язку з перевищенням меж необхідної чи уявної оборони (ст. 118 КК України);

- убивство через необережність, якщо потерпіла особа діяла в ситуації крайньої необхідності (ст. 119 КК України).

Враховуючи те, що об'єктом домашнього насильства можуть бути окремі члени сім'ї, існують такі типи сімейного насильства: з боку батьків стосовно дітей; з боку одного з подружжя стосовно іншого; з боку дітей та онуків стосовно їх родичів.

Убивства, скоєні у зв' язку із застосуванням домашнього насильства, також можна класифікувати, а саме:

1) за способом вчинення: із застосуванням сексуального насильства; із застосуванням фізичного насильства, катування; із застосування психологічного насильства;

2) із застосуванням знарядь злочинного посягання: із застосування вогнепальної зброї; із застосування холодної зброї; із застосування інших предметів, які є в домашньому побуті.

Залежно від використання в процесі підготовки, вчинення та приховування вбивства будь-яких знарядь можна виділити злочини, вчинені з використанням 
певних засобів, із застосуванням інших предметів, які є в домашньому побуті та злочини, вчинені без використання будь-яких засобів [19, с. 152].

За ступенем підготовленості вбивства, вчинені із застосуванням домашнього насильства, можна розподілити на 3 групи: убивства, вчинені раптово, без підготовки та приховування; убивства, вчинені на замовлення; убивства, із застосуванням домашнього насильства, приховані інсценуванням (самогубство, безвісне зникнення особи, нещасний випадок тощо).

Серед убивств, вчинених із застосуванням домашнього насильства, більшість вчиняється раптово, мають ситуаційний характер, без підготовки та заздалегідь продуманого умислу. Винна особа залишає багато доказів, що підтверджують ії вину, або вона навіть сама зізнається в скоєному. Особи жертви та кривдника в білышості випадків перебувають у стані алкогольного чи наркотичного сп'яніння.

Механізм вчинення вбивств у сім'ї характеризується раптовістю виникнення наміру. Так у результаті вивчення кримінальних проваджень встановлено, що 82,8 \% злочинщів прийняли рішення раптово, 8,6 \% - протягом доби, 4,3 \% - протягом тижня, 1,4 \% -протягом місяця, а 2,9 \% - протягом року. У рідких випадках мали місце попередня розробка сценарію злочину і дії по забезпеченню власного алібі.

Для сімейно-побутових насильницьких злочинів не властивий груповий характер, оскільки практично всі вони відбуваються на грунті особистісних неприязних стосунків, яким, як правило, передує двосторонній конфлікт. Вивчення місця й часу вчинення злочинів у сім'ї дозволяє визначити деякі тенденщії та ситуащії, що провокують вчинення конкретних видів злочинів, і дає можливість прогнозувати ситуацію та успішно планувати розслідування злочину.

За місцем вчинення вбивства, із застосуванням домашнього насильства можна розподілити таким чином: скоєні в приміщенні (будинку, гаражі, господарських спорудах тощо); скоєні за межами приміщення (подвір'я, город та інше).

Головною ознакою вбивств, скоєних із застосуванням домашнього насилля, $\epsilon$ вчинення даного злочину в сім'ї чи в межах місця проживання осіб, які перебувають чи перебували в родинних зв' язках або спільно проживали.

За часом скоєння вбивства, скоєні із застосуванням домашнього насильства, не мають особливих ознак. Можуть бути вчинені як удень, так і вночі, робочі, вихідні чи святкові дні. Але ж на практиці ми можемо спостерігати, що саме більшість скоєних побутових убивств припадає на святкові дні, коли особи перебувають в стані алкогольного сп' яніння.

Слідчий, проаналізувавши на початковому етапі розслідування, до якого виду відноситься вбивство, зможе оперативно та в повному обсязі зібрати докази на місці злочину. Це можуть бути сліди крові, знаряддя вбивства, характер тілесних ушкоджень як на тілі жертви, так і на тілі злочинщя. Що своєю чергою спростить та прискорить процес розслідування злочину.

Практичне значення отриманих результатів, а саме формування криміналістичної класифікації вбивств, вчинених у зв' язку з домашнім насильством, полягає в тому, що вона є складовим елементом для подальшого розроблення методики розслідування даних злочинів. Інформащія, отримана в ході проведення даного дослідження, може бути рекомендована для проведення подальших досліджень та використана в наступних сферах: 
1) у навчальному процесі - для підготовки навчально-методичних видань 3 питань розслідування та боротьби з домашнім насильством, при проведенні лекцій і семінарських занять з дисципліни «Криміналістика»;

2) у науково - дослідній сфері - для проведення подальших досліджень щодо особливостей розслідування вбивств, вчинених у зв'язку з домашнім насильством; розроблення методики розслідування зазначених злочинів для подалышого практичного використання органами досудового розслідування; аналіз факторів, які сприяють вчиненню домашнього насильства, на основі яких висунення рекомендацій щодо його запобігання;

3) у правозастосовній діяльності - при підготовці методичних рекомендацій для відповідних підрозділів Національної поліції України, метою діяльності яких є запобігання домашньому насильству та кримінальним правопорушенням взагалі; запропонувати рекомендації, спрямовані на вдосконалення тактики розслідування зазначених правопорушень.

4) у законотворчій діяльності - для подальшої розробки та винесення рекомендащій щодо запровадження на державному рівні нових та вдосконалення вже існуючих законотворчих норм, направлених на профілактику та боротьбу зі злочинністю у зв' язку з домашнім насильством;

Висновки. Отже, розробка окремої криміналістичної класифікації вбивств, скоєних із застосуванням домашнього насильства, є структурним елементом методики розслідування даної категорії злочинів, що безпосередньо необхідна для ефективного розслідування та забезпечення правосуддя.

Виходячи із зазначеного, доцільним, у першу чергу, є внесення змін до КК України, а саме: доповнення ч. 2 ст. 115 пунктом про вчинення вбивства, вчиненого із застосуванням домашнього насильства, або ст. 67 КК України «Обставини, які обтяжують покарання». Через те виділення даного злочину для окремої криміналістичної класифікащії $є$ необхідним.

Отже, на підставі аналізу слідчої та судової практики, позицій науковців, встановлено, що основними критеріями для здійснення криміналістичної класифікації вбивств із застосуванням домашнього насильства є суб'єкт злочину (кривдник або жертва домашнього насильства); місце вчинення злочину (обов' язкова ознака спільне місце проживання); вбивство, скоєне із застосуванням рідного типу насильства (економічне, фізичне, психологічне тощо); ступінь підготовленості (у більшості випадків ефект раптово виниклого умислу).

В основу криміналістичної класифікації вбивств, вчинених із застосуванням домашнього насильства, мають бути покладені два взаємопов' язані критерії: кримінально-правовий, що визначає нормативну суть класифікації, передбаченої законом, та криміналістичний, що враховує чинники, пов'язані зі специфікою виявлення та розкриття вбивств даної категорії, залежно від особливостей предмета посягання, обстановки підготовки, вчинення та приховування злочину, його механізму та способів, типології особи злочинця, мети та мотивації злочинних дій тощо.

Перелічені класифікації вбивств із застосуванням домашнього насильства мають рекомендаційний характер та практичне значення, але залишаються актуальними в контексті розробки зазначеної методики та потребують подальшого дослідження та вдосконалення. 


\section{Використані джерела:}

1. Кримінальний кодекс України: закон України від 05.04.2011 № 2341-ІІІ / / БД «Законодавство України» / ВР України. URL: https://zakon.rada.gov.ua/laws/show/2341-14 (дата звернення 03.02.2020).

2. Про запобігання та протидію домашньому насильству: Закон України від 07.12.2017 № 2229-VIII / / БД «Законодавство України» / ВР України. URL: https:/ zakon. rada.gov.ua/laws/show/2229-19 (дата звернення 03.02.2020).

3. Дудоров О. О., Хавронюк М. І. Відповідальність за домашне насильство і насильство за ознакою статі (науково-практичний коментар новел Кримінального кодексу України) за ред. М. І. Хавронюка. Київ: Ваіте, 2019. 288 с.

4. Побутова злочинність Юридична енщиклопедія [у 6 т.] ред. кол. Ю. С. Шемшученк. Київ: Українська енциклопедія ім. М. П. Бажана, 2002. 720 с.

5. Коржанський М. Й. Кваліфікація злочинів проти особи та власності. Київ, 1996. 144 c.

6. Конституція України (Відомості Верховної Ради України (ВВР), 1996, № 30, ст. 141)

7. Статистична інформація про стан злочинності та результати прокурорсько-слідчої діяльності. Генеральна прокуратура України. URL: https://www.gp.gov.ua/ua/stst20 11.html?dirid=113651\&libid=100820\&c=edit\&_c=fo (дата звернення 03.02.2020).

8. Баулін Ю. В. Протиправність як ознака вбивств. Кримінально-правова охорона життя та здоров'я особи: Матер. наук.-практ. конф. (Харків 22-23 квітня 2004 р.). Харків: Юрінком Інтер, 2004. С. 18-19.

9. Андреева Л. А. Влияние жестокости преступного поведения на уголовную ответственность. Издательство «Юридический центр Пресс», 2002. 210 с.

10. Образцов В. А. Криминалистическая классификация преступлений. Красноярск. Изд-во Краснояр. ун-та,1988. 176 с.

11. Жеребкін В. Є. Логіка: підручник для юридичних вузів і факультетів. 3-є вид., стереотипне. Харків. Основа, 1999. 256 с.

12. Кримінальне право України. Загальна частина. під ред. М. І. Бажанова, В.В.Сташиса, В. Я. Тація. - Київ-Харків: Юринком Інтер -Право, 2002. 414 с.

13. Данышин И. Н. Введение в криминологическую науку. Харків. Право, 1998. 144 с.

14. Головин А. Ю. Криминалистическая систематика. Москва. «ЛексЭст», 2002. 308 с.

15. Кривоченко Л. Н. Классификация преступлений. Харків: Вища школа, 1983.129 с.

16. Чурилов С. Н. Методика расследования преступления: общие положения. Москва. Юстицинформ, 2009. 232 с.

17. Розслідування злочинів у сфері господарської діяльності: окремі криміналістичні методики: монографія. В. Ю. Шепітько, В. О. Коновалова, В. А. Журавель та ін.; за ред. В. Ю. Шепітька. Харків: Право, 2006. 624 с.

18. Новели законодавства про запобігання та протидію домашньому насильств: матеріали міжнародного круглого столу (27 вересня 2019 року). Укладачі: С. Мінченко, Г. Попов, О. Гладун, С. Штанько. Київ: Національна академія прокуратури України, 2019. 184 с.

19. Гусєва В. О. Криміналістична класифікація злочинів: сучасний стан наукового забезпечення та перспективи подалыших досліджень. Націюнальний юридичний журнал: теорія та практика. 2019. № 3, ч. 1 (Mai). С. 151-156.

\section{References:}

1. Kryminalnyi kodeks Ukrainy: zakon Ukrainy vid 05.04.2011 № 2341-III // BD «Zakonodavstvo Ukrainy» / VR Ukrainy. URL: https://zakon.rada.gov.ua/laws/show/2341-14 [in Ukrainian]. 
2. Pro zapobihannia ta protydiiu domashnomu nasylstvu: Zakon Ukrainy vid 07.12.2017 № 2229-VIII // BD «Zakonodavstvo Ukrainy» / VR Ukrainy. URL: https:// zakon. rada. gov. ua/laws/show/2229-19 [in Ukrainian].

3. Dudorov, O. O., Khavroniuk, M. I. (2019)Vidpovidalnist za domashnie nasylstvo i nasylstvo za oznakoiu stati (naukovo-praktychnyi komentar novel Kryminalnoho kodeksu Ukrainy) M. I. Khavroniuk (Ed.). Kyiv: Vaite. [in Ukrainian].

4. Pobutova zlochynnist Yurydychna entsyklopediia. (2002) (Vol. 1-6); Vol. 6. Ju. S. Shemshuchenk (Ed.). Kyiv. [in Ukrainian].

5. Korzhanskyi, M. Y. (1996) Kvalifikatsiia zlochyniv proty osoby ta vlasnosti. Kyiv. [in Ukrainian].

6. Konstytutsiia Ukrainy (1996) Vidomosti Verhoonoyi Rady Ukrainy- Verkhovna Rada (BBR) information, 30, art. 141. [in Ukrainian].

7. Statystychna informatsiia pro stan zlochynnosti ta rezultaty prokurorsko-slidchoi diialnosti. Heneralna prokuratura Ukrainy. URL: https://www.gp.gov.ua/ua/stst2011.html?d irid $=113651 \&$ libid $=100820 \& c=$ edit\&_c $=$ fo [in Ukrainian].

8. Baulin, Yu. V. (2004) Protypravnist yak oznaka vbyvstv. Kryminalno-pravova okhorona zhyttia ta zdorov'ia osoby: Mater. nauk.-prakt. konf. (Kharkiv 22-23 kvitnia 2004 r.). Kharkiv: Yurinkom Inter-Mater. Ph.D. Conf. (Kharkiv, 22-23 April 2004, 18-19. Harkiv: Jurinkom Inter. [in Ukrainian].

9. Andreeva, L. A. (2002) Vlyianye zhestokosty prestupnoho povedenyia na uholovnuiu otvetstvennost. Yzdatelstvo «Iurydycheskyi tsentr Press». [in Ukrainian].

10. Obraztsov, V. A. (1988) Krymynalystycheskaia klassyfykatsyia prestuplenyi. Krasnoiarsk. Yzd-vo Krasnoiar. un-ta. [in Russian].

11. Zherebkin, V. Ye. (1999) Lohika: pidruchnyk dlia yurydychnykh vuziv i fakultetiv. Vol. 3. Kharkiv: Osnova. [in Ukrainian].

12. Kryminalne pravo Ukrainy. Zahalna chastyna. (2002) M. I. Bazhanov, V. V. Stashys, V. Ya. Tatsii. (Eds.) Kyiv-Harkiv: Jurinkom Inter - Pravo. [in Ukrainian].

13. Danshyn, Y. N. (1998) Vvedenye v krymynolohycheskuiu nauku. Kharkiv. Pravo. [in Ukrainian].

14. Holovyn, A. Yu. (2002) Krymynalystycheskaia systematyka - Moskva. «LeksЭst» [in Russian].

15. Kryvochenko, L. N. (1983) Klassyfykatsyia prestuplenyi. Kharkiv: Vyshcha shkola. [in Ukrainian].

16. Churylov, S. N. (2009) Metodyka rassledovanyia prestuplenyia: obshchye polozhenyia. Moskva. Yustytsynform. [in Russian].

17. Rozsliduvannia zlochyniv u sferi hospodarskoi diialnosti: okremi kryminalistychni metodyky: monohrafiia. V. Yu. Shepitko, V. O. Konovalova, V. A. Zhuravel. (Eds.) et al. V. Yu. Shepitko (Ed.). Kharkiv: Pravo. [in Ukrainian].

18. Novely zakonodavstva pro zapobihannia ta protydiiu domashnomu nasylstvu. Materialy mizhnarodnoho kruhloho stolu (27 veresnia 2019 roku)-Materials of the international round table (September 27, 2019). (2019). S. Minchenko, H. Popov, O. Hladun, S. Shtanko (Eds.). Kyiv: Natsionalna akademiia prokuratury Ukrainy.[in Ukrainian].

19. Husieva, V. O. (2019) Kryminalistychna klasyfikatsiia zlochyniv: suchasnyi stan naukovoho zabezpechennia ta perspektyvy podalshykh doslidzhen. Natsionalnyi yurydychnyi zhurnal: teoriia ta praktyka- National Law Journal: Theory and Practice, 3, part. 1, 151-156. [in Moldavia]. 
Шаповал Е. А.,

адьюнкт отдела организации

образовательно-научной подготовки

Харьковского национального

университета внутренних дел

(г. Харьков, Украина)

\section{КРИМИНАЛИСТИЧЕСКАЯ КЛАССИФИКАЦИЯ УБИЙСТВ, СОВЕРШЕННЫХ С ПРИМЕНЕНИЕМ ДОМАШНЕГО НАСИЛИЯ}

В статье раскрыто криминалистическую классификацию убийств, совершенных с применением домашнего насилия. Исследовано новизну и необходимость рассмотрения данной темы, и разработку криминалистической методики расследования данного вида убийств. На основе научной литературы и практики органов досудебного следствия рассмотрены критерии для формирования криминалистической классификации убийств, совершенных в связи с применением домашнего насилия. Определено понятие классификации, убийства и домашнего насилия.

Ключевые слова: криминалистическая классификация, убийство, домашние насилие, методика, расследование.

Shapoval K.,

Adjunct Department of the organization educational and scientific training of Kharkiv National University of Internal Affairs (Kharkiv, Ukraine)

\section{CRIMINALISTIC CLASSIFICATION OF MURDER VIOLENCE}

The author examines the criteria for forensic classification of homicides in connection with the use of domestic violence. Describes domestic violence issues and examples of counteraction at national level. Also the author justifies the novelty and necessity of addressing this topic, due to the lack of a methodology for investigating domestic violence killings.

The author had explored the criteria for forming a forensic classification of homicide committed in connection with domestic violence have been considered based on the scientific literature and practice of the pre-trial investigation authorities. The scientists who have already worked in this field are noted also were indicated.

The purpose of this article is to analyze in detail the various typical approaches to classifying homicides that are committed with the use of domestic violence (domestic killings) and to determine its optimal criteria. There fore, the novelty is contained in determining the criteria for constructing a comprehensive forensic classification of this type of crime. The development of a homicides classifications is conditioned by the practical needs of improving the investigation of this category of crimes, developing the methodology for investigating them, and is a significant element in the formation of criminological analysis, the features of the determination of various types of crimes, and accordingly the development of preventive measures to counter domestic violence and negative violence.

The author had defined the notion of classification, murder and domestic violence.

Based on the analysis of investigative practice, criminal law and criminal procedural law, the positions of scientists, it has been established that the main criteria for forensic classification 
of homicide committed with domestic violence are: the subject of the crime (the offender or the victim of domestic violence); the place of the crime (mandatory residence sign); murder perpetrated using domestic violence (economic, physical, psychological, etc.); degree of readiness (in most cases, the effect of a sudden emergence of intent).

Keywords: forensic classification, murder, domestic violence, crime, life, killer. 